\title{
Prevalence of oral and maxillofacial soft tissue calcifications in dental panoramic radiography: A retrospective study
}

\author{
Jayapriya Ramadurai ${ }^{1, *}$, T.N. Umamaheswari ${ }^{2}$ \\ ${ }^{1}$ PG Student, ${ }^{2}$ Professor, Dept. of Oral Medicine and Radiology, Saveetha Dental College and Hospital, Saveetha University, \\ Chennai, India
}

*Corresponding Author: Jayapriya Ramadurai

Email: drjay2407@gmail.com

\begin{abstract}
Introduction: The aim of the study was to determine the prevalence of soft tissue calcifications in digital dental panoramic radiography.

Materials and Methods: Digital panoramic radiographs of 1314 dental patients who visited the Oral Radiology department from November 2017 to January 2018 were analyzed for soft tissue calcifications.

Results: The most common soft tissue calcification identified were submandibular sialolith $30.43 \%$, followed by $17.39 \%$ of phlebolith and $17.39 \%$ of calcified atherosclerotic plaques, $13.04 \%$ of, tonsillolith $8.69 \%$ of calcified stylohyoid ligament and $4.34 \%$ arteriosclerosis.

Conclusion: There is low prevalence of soft tissue calcifications which increases with age, Atherosclerotic plaque occurs in male than in female. Once a soft tissue calcification is diagnosed incidentally in a routine dental radiograph it can aid in prevention of the disease.
\end{abstract}

Keywords: Soft tissue calcifications, Sialolith, phlebolith, Atherosclerotic plaque, Panaromic radiography, Prevalence.

\section{Introduction}

Calcification means accumulation of calcium salts in the body tissues, normally calcium phosphate gets deposited accumulated in the skeletal tissues but abnormally when it occurs in an unordered fashion in soft tissues it is referred to as heterotopic calcification. ${ }^{1}$ Soft tissue calcifications are categorized into dystrophic, metastatic and idiopathic calcifications. Dystrophic calcification occurs without a systemic mineral imbalance that is the serum calcium and phosphate levels are normal. ${ }^{2}$ This calcification is usually localized to the site of injury. The soft tissues injury like infection, inflammation, trauma, blunt injury are the most common causes for dystrophic calcifications. ${ }^{3}$ Metastatic calcification results when the serum and body tissues have elevated levels of calcium and phosphate this leads to precipitation of minerals into normal tissue. Hyperparathyroidism, hypercalcemia or in malignancy serum calcium is increased or in chronic renal failure serum phosphate levels are increased. ${ }^{4,5}$ Metastatic calcification occurs bilaterally and symmetrically. Idiopathic calcification also called as calcinosis results in deposition of calcium in normal tissues with normal mineral balance. ${ }^{6}$ Dystrophic calcification includes rhinolith, antrolith, phlebolith, tonsillolith, arteriosclerosis, arteriosclerotic plaque, calcified lymph nodes, elongated stylohyoid ligament and myositis ossificans. ${ }^{7-10}$ The most cause for calcification in lymph nodes is deposition of necrotic deposits of malignant tissues which is highly prevalent in post chemotherapy and radiation therapy patients. Tonsilloliths develop due to chronic inflammation of the tonsils, they manifest clinically as yellow or white stones when they are large they protrude from the tonsillar crypts. ${ }^{11}$ Induced by trauma or hemorrhage to the muscles of mastication myositis ossificans develops and if it affects one muscle they are localized if multiple muscles are affected they are generalized in nature. Radiopaque calcifications are asymptomatic, symptoms may be helpful in arriving at a diagnosis. The stylohyoid and stylomandibular ligament along with stylohyoid, stylopharyngeus and styloglossus muscles originate from styloid process and they are termed as the "stylohyoid chain". ${ }^{12,13}$ Sometimes the calcification occurs within the ligament leading to ossification of the stylohyoid ligament and it is clinically manifested as headache, pain on swallowing, yawning and on moving the head laterally. When the panoramic image shows an elongated stylohyoid ligament it can be confirmed as an Eagle's syndrome. ${ }^{14}$

Oral and maxillofacial soft tissue calcifications are incidental findings in routine dental imaging. They are rare but once diagnosed some calcifications may be serious and requires immediate management. The aim of the study was to determine the prevalence of soft tissue calcifications in digital dental panoramic radiography.

\section{Materials and Methods}

Digital panoramic radiographs of 1314 dental patients who visited the oral radiology department from November 2017 to January 2018 were analyzed for soft tissue calcifications. The panoramic images were obtained from OPG machine with specifications like 68 Kilovolt, 9 milliamperage with 12 seconds of exposure time. Each radiograph was taken by a specialized radiology technician. OPG was divided into nine boxes and numbered from 1-9 as shown in Fig. 1. Faulty radiographs, over-projection of structures or lack of clarity in diagnosis were discarded from the study. Table 
1 shows the criteria for diagnosing soft tissue calcifications.

Table 1: Criteria for evaluating soft tissue calcifications

\begin{tabular}{|l|l|}
\hline \multicolumn{1}{|c|}{ Soft tissue calcifications } & \multicolumn{1}{c|}{ Criteria } \\
\hline Antrolith & $\begin{array}{l}\text { Well-defined, smooth or irregular, single Radiopacity seen above the } \\
\text { floor of the maxillary sinus }\end{array}$ \\
\hline Rhinolith & $\begin{array}{l}\text { Well-defined, smooth or irregular, single Radiopacity seen in the antrum } \\
\text { of maxillary sinus }\end{array}$ \\
\hline Phlebolith & $\begin{array}{l}\text { Small, multiple concentric radiopaque rings with a homogenously } \\
\text { radiopaque internal aspect }\end{array}$ \\
\hline Tonsillolith & $\begin{array}{l}\text { Mid-portion of ramus along the oropharyngeal air-way space where } \\
\text { dorsum of tongue crosses the ramus and angle, appears as unilateral, } \\
\text { well-defined, round to oval, small and multiple (cluster) radiopacities. }\end{array}$ \\
\hline Sialolith & $\begin{array}{l}\text { SUBMANDIBULAR SIALOLITH- Below the apices of mandibular } \\
\text { premolars, medial to the angle of mandible and above hyoid bone, } \\
\text { Regular but if close to } \\
\text { hilus of gland it may be irregular, smooth, round, single or multiple } \\
\text { radiopacities } \\
\text { PAROTID SIALOLITH- On upper third of ramus of mandible irregular, } \\
\text { smooth, round, single or multiple radiopacities. }\end{array}$ \\
\hline $\begin{array}{l}\text { Arteriosclerosis or carotid artery } \\
\text { calcifications }\end{array}$ & $\begin{array}{l}\text { Postero-inferior to the angle of the mandible close to intervertebral space } \\
\text { C3-C4 appears as irregular, nodular masses, curvy verticolinear or } \\
\text { irregular radiopaque line }\end{array}$ \\
\hline Calcified stylohyoid ligament & $\begin{array}{l}\text { Between posterior ramus and cervical spine crossing angle of mandible, } \\
\text { below and medial to angle. Radiopaque or outlines more radiopaque, } \\
\text { may be segmented appears tapering, slender, regular, linear and longer } \\
\text { than 3O mm radiopaque outline. }\end{array}$ \\
\hline Myositis ossificans & Radiopacity along of muscle (s) of mastication. \\
\hline Calcified lymph node & $\begin{array}{l}\text { Irregular, lobulated, cauliflower-like, single or multiple radiopacities } \\
\text { seen in submental, submandibular and cervical regions }\end{array}$ \\
\hline Calcified atherosclerotic plaque & $\begin{array}{l}\text { Seen superior to the greater cornua of hyoid bone adjacent to c3 and c4 } \\
\text { vertebra }\end{array}$ \\
\hline
\end{tabular}

\section{Results}

Of the 1314 radiographs examined for evidence of soft tissue calcifications. The age ranges from 4-86 years, of which 632 were male and 682 were female. A total of 23 calcifications $(1.75 \%)$ were identified in 23 individuals, of which 16 were female $(69.5 \%)$ and 7 were male $(30.5 \%)$. The number of soft tissue calcifications according to age group is shown in Graph 1.

\section{Graph 1: Total number of soft tissue calcifications present and absent seen in different age groups}

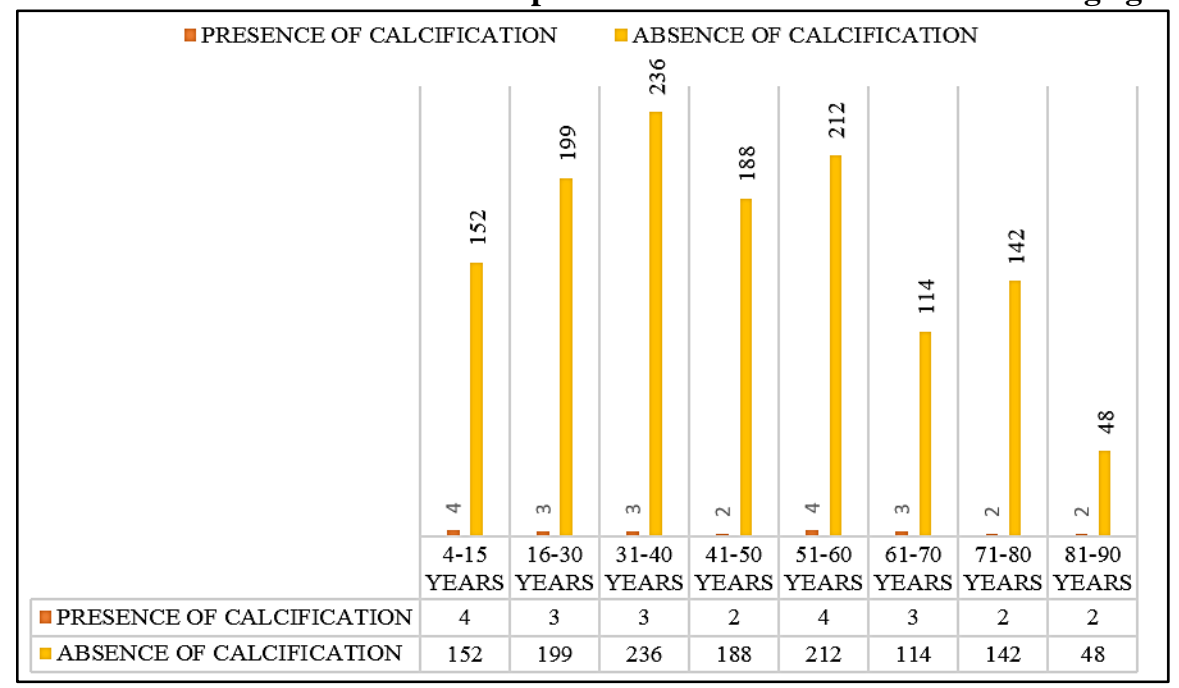


The most common soft tissue calcification identified were submandibular sialolith $30.43 \%$, followed by $17.39 \%$ of phlebolith and $17.39 \%$ of calcified atherosclerotic plaques, $13.04 \%$ of, tonsillolith $8.69 \%$ of calcified stylohyoid ligament and $4.34 \%$ arteriosclerosis. From the total of 1314 subjects the mean age of patients with and without calcification is shown in graph 2 .

\section{Graph 2: Mean age with and without calcifications}
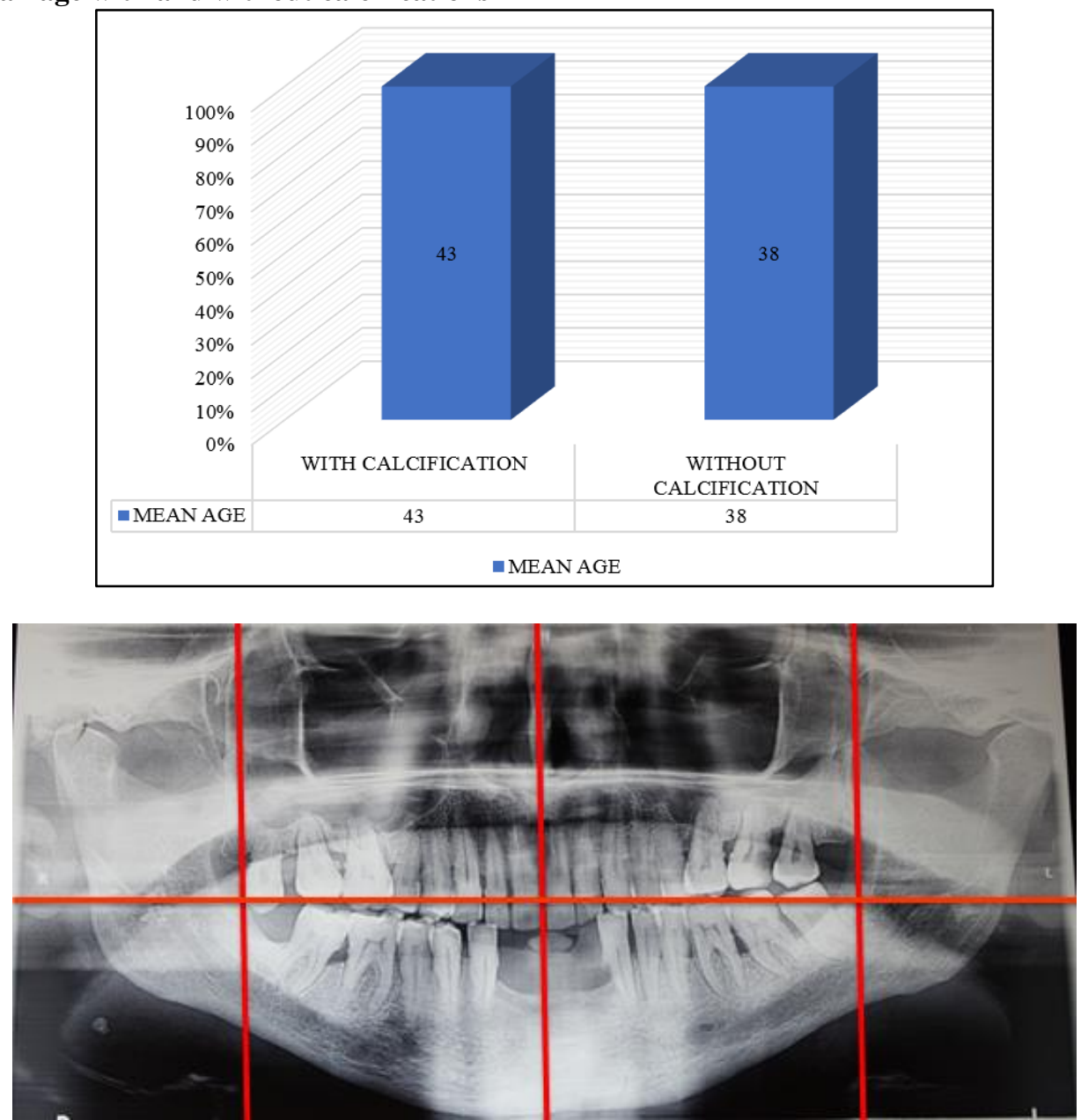

Fig. 1: Shows segmentation of OPG to identify soft tissue calcifications

\section{Discussion}

In this current study the prevalence of soft tissue calcifications was $1.75 \%$ as compared to the study done by Ivonne Garay in 2014 (2.16\%), Janisha Vengalath in $2017(8 \%)$ and Mansour et al. (4\%). ${ }^{15}$ The highly prevalent soft tissue calcification in the current study was submandibular sialolith (30.43\%) followed by atherosclerotic plaque (17.39\%). In this current study sample $30.43 \%$ of submandibular sialolith were projected on the mandibular body or dental roots that were compatible with calcifications of the submandibular gland. ${ }^{16}$ These calcifications were observed under the mandibular border (Fig. 1). Results from previous study by El Deeb reported that sialolithiasis affects $0.01 \%$ to $1 \%$ of the population and found a greater prevalence in men and in the current study we observed a greater prevalence in women which is consistent with our study. In terms of age, a greater prevalence has been reported in the group aged between 30 and $60 .{ }^{17}$ In this current study the mean age of patients was 47 years.

The highly prevalent soft tissue calcification was atherosclerotic plaque was Atherosclerotic plaques commonly along the bifurcation level of the carotid artery. Its prevalence is between $3 \%$ and $5 \%$ of the population. ${ }^{18}$ In this current study, a prevalence of $17.39 \%$ of atheromas was noted in male patients over 50 years of age with a mean age of 61.5 years. $2-11 \%$ prevalence rate of atheroma was reported in a hospital based study done on dental patients. ${ }^{19}$ Studies done by Friedlander AH in 1998 and Ohba T in 2003 have shown that the incidence of atherosclerosis is more in men than in women. Until menupause females are protected because of the presence of female sex harmones like estrogen and progesterone leads to reduced prevalence of atheroma in women. ${ }^{20}$ The causes of arterosclerosis 
and atheroma which leads to accumulation of cholesterol in the vessel walls are atherosclerosis are smoking, obesity, advanced age, improper diet, high stress, hypertension, diabetes mellitus inadequate blood supply, and lack of physical exercise. The most common cause of mortality worldwide is coronary heart disease, cancer, and stroke. Asians have a lower rate of coronary heart disease and a higher prevalence of stroke. In India ageadjusted prevalence rate of stroke was between 250 and $350 / 100000$ of the population. ${ }^{21}$

In the current study $13.04 \%$ tonsillolith were noted comparative to previous study by Ivonne Garay in 2014, $0.98 \%$ in men and $2.83 \%$ in women, Janisha Vengalath in $2017(4.2 \%)$ the current study has higher prevalence of tonsillolith. ${ }^{22}$ Tonsilloliths are calcifications within a tonsillar crypt, involve primarily the palatine tonsil caused by dystrophic calcification as a result of chronic inflammation. Tonsilloliths are very uncommon. Clinical symptoms includes non-specific chronic halitosis, irritable cough, dysphagia, otalgia and foreign body-like sensation or foul taste. Patients with tonsillolithiasis may also be asymptomatic, with their lesions being discovered incidentally on panoramic radiographs. The current study shows a prevalence of $17.39 \%$ of phleboliths phlebolith are rare and no previous studies had incidence of phleboliths. The principle causes of phlebolith calcification occurrence within the oral mucosa are inflammation, trauma, debris and vascular for. Occurrence of multiple phleboliths is considered a characteristic feature for hemangiomas and vascular malformations in the oral and maxillofacial region. $^{23}$

\section{Conclusion}

Even though soft tissue calcifications are incidental findings in the oral and maxillofacial region with low prevalence rate. The detection of some calcifications which are pathognomic to a specific disorder. Once identified it may be of high importance especially in patients with carotid artery calcifications and tuberculosis. This will eventually improve the prognosis of the disease. The anatomic location, number, distribution, and pattern of the calcifications are important diagnostic criteria in radiographic evaluation of soft tissue calcifications.

\section{References}

1. White S, Pharoah M. Radiología Oral: principios e interpretación. 1st ed. Barcelona: Harcourt; 2002. pp: 552-65.

2. Thakur J, Minhas R, Thakur A, Sharma D, Mohindroo N. Giant tonsillolith causing odynophagia in a child: a rare case report. Cases J 2008; 1: 50.

3. Freitas A, Rosa J, Souza I. Radiología Odontológica. $6^{\mathrm{a}}$ ed. São Paulo: Artes Médicas; 2004. pp: 102-155.

4. Eisenkraft BL, Som PM. The spectrum of benign and malignant etiologies of cervical node calcification. AJR Am J Roentgenol. 1999;172:1433-1437.
5. Ram S, Siar CH, Ismail SM, Prepageran N. Pseudo bilateral tonsilloliths: a case report and review of the literature. Aust Dent J. 1991;36:94-101.

6. Shigehara H, Honda Y, Kishi K, Sugimoto T Radiographic and morphologic studies of multiple miliary osteomas of cadaver skin. Oral Surg Oral Med Oral Pathol Oral Radiol Endod. 86(1):121-125.

7. Romero De Leon E, Aguirre A. Oral cysticercosis. Oral Surg Oral Med Oral Pathol Oral Radiol Endod. 79(5):572-577. terature. Oral Surg Oral Med Oral Pathol Oral Radiol Endod 2004;98:110114.

8. De Moura M, Madureira D, Noman-Ferreira L, Abdo E, Aguiar E, Freire A. Tonsillolith: A report of three clinical cases. Med Oral Patol Oral Cir Bucal. 2007;12:130-133.

9. Ohba T, Takata Y, Ansai T, Morimoto Y, Tanaka T, Kito $\mathrm{S}$. Evaluation of calcified carotid artery atheromas detected by panoramic radiograph among 80 -year-olds. Oral Surg Oral Med Oral Pathol Oral Radiol Endod. 2003;96:647-50.

10. Taguchi A, Suei Y, Sanada M, Higashi Y, Ohtsuka M, Nakamoto T. Detection of vascular disease risk in women by panoramic radiography. J Dent Res. 2003;82:838-43.

11. Inzitari D, Eliasziw M, Gates P, Sharpe BL, Chan RK, Meldrum HE. The causes and risk of stroke in patients with asymptomatic internal-carotid-artery stenosis. North American Symptomatic Carotid Endarterectomy Trial Collaborators. N Engl J Med. 2000;34:1693-701.

12. Browner WS, Pressman AR, Nevitt MC, Cauley JA, Cummings SR. Association between low bone density and stroke in elderly women. The study of osteoporotic fractures. Stroke. 1993;24:940-6.

13. Bonithon-Kopp C, Scarabin PY, Taquet A, Touboul PJ, Malmejac A, Guize L. Risk factors for early atherosclerosis in middle - aged French women. Aterioscler Thromb. 1991;11:966-72.

14. Monsour P, Romaniuk K, Hutchings R. Soft tissue calcifications in the differential diagnosis of opacities superimposed over the mandible by dental panoramic radiography. Aust Dent J. 1991;36:94-101.

15. Talbott EO, Guzick DS, Sutton-Tyrrell K, McHugh-Pemu KP, Zborowski JV, Remsberg KE. Evidence for association between polycystic ovary syndrome and premature carotid atherosclerosis in middle aged women. Arterioscler Thromb Vasc Biol. 2000;20:2414-21.

16. Mathews KA, Owens JF, Kuller LH, Sutton-Tyrrell K, Lassila HC, Wolfson SK. Stress-induced pulse pressure changes predicts women's carotid atherosclerosis. Stroke. 1998;29:1525-30.

17. Ertas ET, Sisman Y. Detection of incidental carotid artery calcifications during dental examinations: panoramic radiography as an important aid in dentistry. Oral Surg Oral Med Oral Pathol Oral Radiol Endod. 2011;112:1117.

18. El Deeb M, Holte N, Gorlin RJ. Submandibular salivary gland sialoliths perforated through the oral floor. Oral Surg Oral Med Oral Pathol Oral Radiol Endod. 1981;51:134-139.

19. Scolozzi P, Laurent F, Lombardi T, Richter M. Intraoral venous malformation presenting with multiple phleboliths. Oral Surg Oral Med Oral Pathol Oral Radiol Endod. 2003;96:197-200.

20. Maheswari TN, Gnanasundaram N. Stress related oral diseases-A research study. IJPBS. 2010;1(3):1-0.

21. Sridhar T, Gnanasundaram N. Ultrasonographic Evaluation of Salivary Gland Enlargements: A Pilot Study. International Journal of Dental Sciences and Research. 2013;1(2):28-35. 
22. Kamikawa RS, Fenyo-Pereira M, Fernandes MA, Meurer MI. Study of the localization of radiopacities similar to calcified carotid atheroma by means of panoramic radiography. Oral Surg Oral Med Oral Pathol Oral Radiol Endod. 2006;101:374-378.

23. Andretta M, Tregnaghi A, Prosenikliev V, Staffieri A.

Current opinions in sialolithiasis diagnosis and treatment. Acta Otorhinolaryngolo Ital. 2005;25:145-149. 